\title{
Fiber reinforced composite bridge as a replacement for missing upper permanent lateral incisor - a case report
}

\author{
Ana Todorović, Danica Popović, Igor Djordjević, Vojkan Lazić \\ University of Belgrade, School of Dental Medicine, Department for Prosthodontics, Belgrade, Serbia
}

\begin{abstract}
SUMMARY
Hypodontia of upper lateral incisors is significant aesthetic problem in young people. Ideal solution to this problem would be an implant placement, but there is a problem of unfinished growth and development. It is therefore necessary to have a temporary solution in order to maintain normal stomatognathic system functions and solve aesthetic problems until the final restoration is placed.

The aim of this study was to show the possibility of treating hypodontia of permanent upper lateral incisors by creating adhesive bridge in one visit.

A 15-year-old patient was referred to the Department for Prosthodontics, School of Dental Medicine in Belgrade with hypodontia of permanent upper lateral incisors. The patient had braces until 14 years of age after which she was rehabilitated with partial denture that was neither aesthetically nor functionally acceptable solution for her and significantly affected her emotional security. The adhesive bridge was made using GC composite fibers and a set of GC composite materials for the purpose of temporary replacement of missing teeth. This treatment provided good functional and aesthetic results. The space for the placement of two endosseous implants is preserved and a period of adaptation positively influenced the patient's social development in sensitive adolescent age.

Keywords: adhesive bridges; hypodontia of lateral incisors; fiber-reinforced composites
\end{abstract}

\section{INTRODUCTION}

Hypodontia or the lack of permanent upper lateral incisors is caused by the absence of formation of tooth germs in the jaw and occurs in $20 \%$ of population, more often in permanent dentition $[1,2]$. It is significant functional and aesthetic problem for young people in adolescence. Treatment with restorations of high aesthetic value is mainly limited by unfinished growth and development of body.

Replacement of missing anterior teeth, especially in children, is a major challenge for clinicians. Therefore, multidisciplinary approach with cooperation of children's dentist, orthodontist, prosthodontist and oral surgeon is of great importance in order to preserve the space and supporting tissues until definitive therapy. Partial dentures are often treatment of choice in children until the eruption of permanent teeth is completed, reduction of alveolar bone and final forming of the pulp chamber for subsequent preparation for definitive dental restoration [3]. However, lack of care for denture by a child and its wear and plaque accumulation are the greatest limitations of this treatment [4]. Metal ceramic bridges in these cases have also to be postponed until marginal gingiva stability is established. Also, rigid fixation between two teeth would lead to difficult bone growth between them. Maryland bridges can be used as a replacement of missing teeth, but they are criticized for the lack of aesthetics caused by the presence of metal base and weak bonding between metal extensions and enamel $[5,6,7]$.
Dental implants, on the other hand, are not recommended until the end of the growth period; due to ankylotic implant-bone bond that does not allow their growth together with facial bones presenting danger of their apical dislocation $[8,9]$. Minimally invasive therapy is good choice in these cases. Adhesive bridges are an economical and simple solution that gives good aesthetic results in a single visit in order to preserve space for future implant placement. Fiber reinforced composites (FRC) are resin based materials that contain fibers to improve their physical characteristics. They were first mentioned in the literature in 1960s when Glass fibers were used for reinforcement of polymethyl methacrylate [10]. Different types of fibers, such as glass, carbon, kevlar and polyethylene fibers were added to composite materials in order to improve their properties [11]. Our study described the use of FRC technology in the production of adhesive bridges in a patient with hypodontia of permanent upper lateral incisors.

The aim of this study was to show one treatment option for hypodontia of permanent upper lateral incisors by creating adhesive composite bridge in one visit.

\section{CASE REPORT}

A 15 years old female patient was referred to the Department of Prosthodontics, School of Dental Medicine, University of Belgrade, for the treatment of hypodontia of 


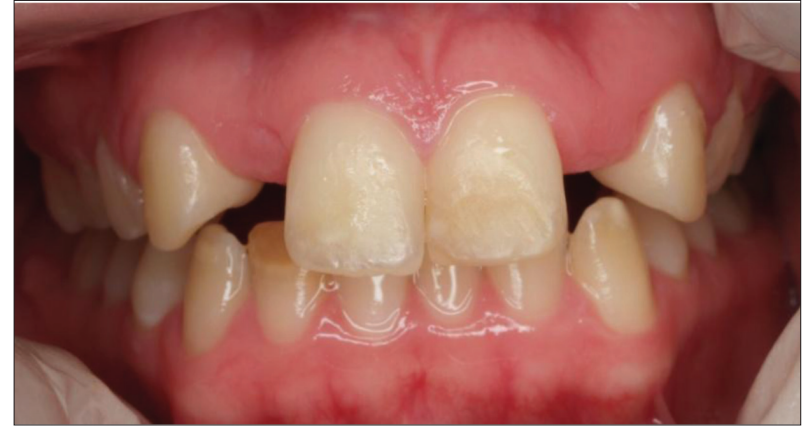

Figure 1. Dental status of the patient at the beginning of treatment (hypodontia of upper permanent lateral incisors)

Slika 1. Izgled pacijenta na početku (hipodoncija gornjih stalnih lateralnih sekutića)

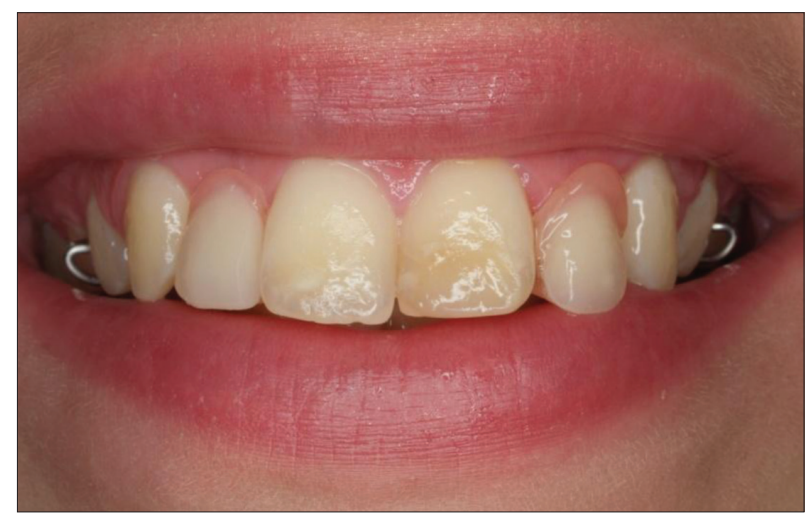

Figure 2. Partial acrylic denture

Slika 2. Parcijalna akrilatna proteza („žabica“) in situ

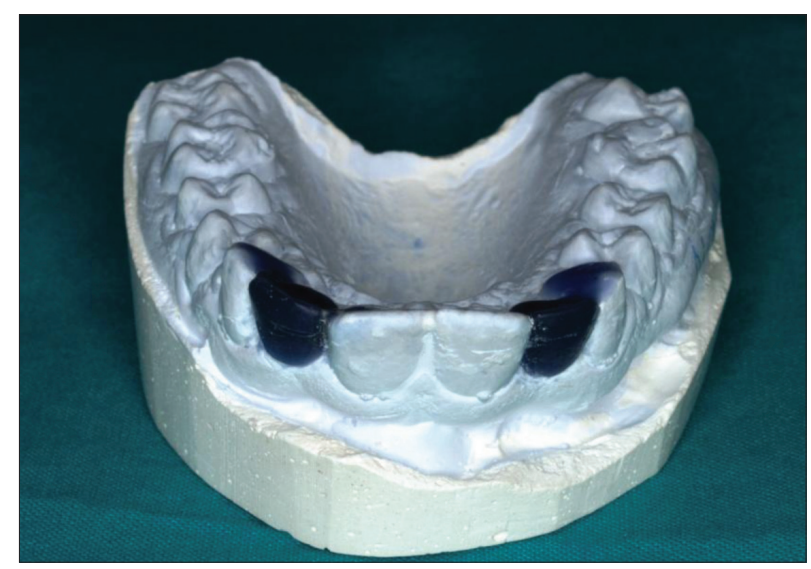

Figure 3. Study model with completed diagnostic modeling in wax Slika 3. Model za studije sa završenim dijagnostičkim modelovanjem u vosku

permanent upper lateral incisors (Figure 1). During the past two years she wore a fixed orthodontic appliance, and at the end of orthodontic treatment at the age of 14 she was rehabilitated with partial denture as a temporary solution. Partial denture was not satisfactory treatment aesthetically or functionally causing the patient emotional insecurity (Figure 2).

After clinical examination and analysis of panoramic $\mathrm{x}$-ray, impressions were taken for the study models. Their analysis in an articulator showed sufficient interocclusal space between the upper and lower anterior teeth to create fiber-reinforced adhesive bridge without the need for

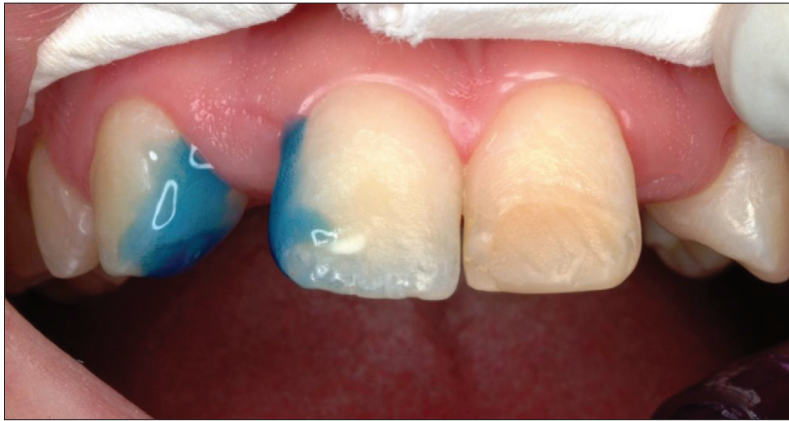

Figure 4. Surface preparation, enamel etching with phosphoric acid Slika 4. Priprema površine gleđi nagrizanjem ortofosfornom kiselinom

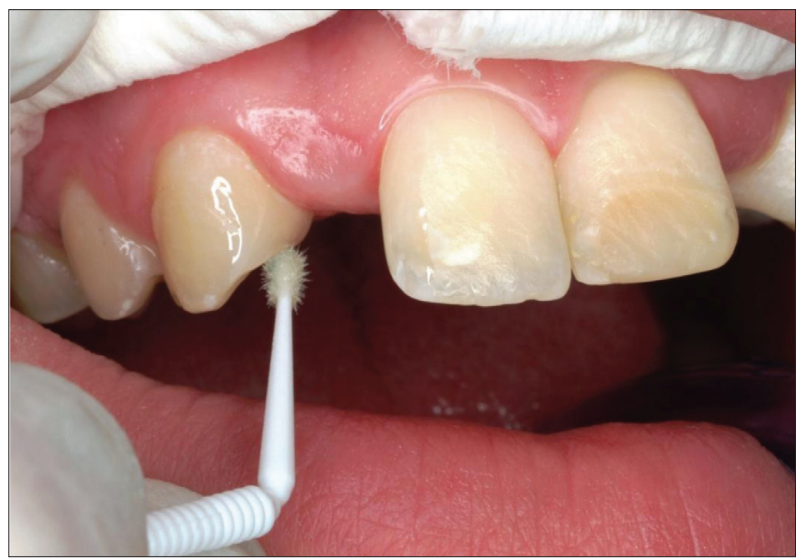

Figure 5. Application of special adhesive to enamel before adaptation of fibers

Slika 5. Nanošenje specijalnog adheziva za gleđ pre adaptacije vlakana

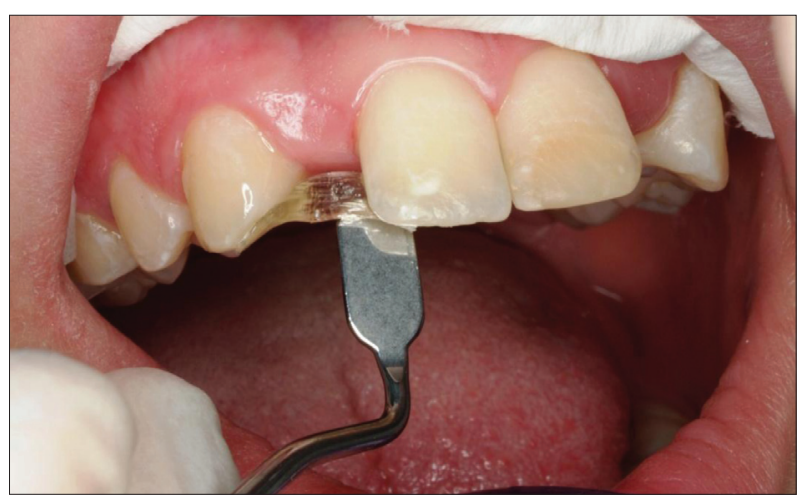

Figure 6. Base body modeling of the bridge from fibers and their placing on the teeth.

Slika 6. Oblikovanje osnove tela mosta od vlakana i njihovo postavljanje na zube

preparation of abutment teeth. Diagnostic modeling of upper lateral incisors was done so that the patient would have insight into the future restoration and a silicone key was designed for modeling missing incisors on the basis of test modeling in wax (Figure 3 ). In one visit, the adhesive bridge was made using a GC everStick C \& B Fiber (GC, Europe) and a set of GC Gradia composite materials (GC, Europe) with the aim of temporary restoration of missing teeth. EverStick C \& B fiber is made of over $4000 \mathrm{E}$ salinized glass-fiber surrounded by bis-GMA and polymethyl methacrylate (PMMA). The required length of the fibers was measured on the study model. The fibers 


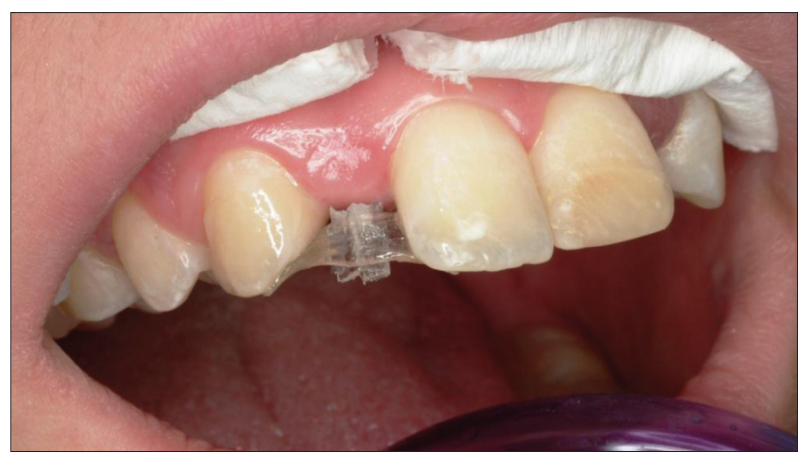

Figure 7. Appearance of the adhesive fiber bridge after light curing Slika 7. Izgled tela adhezivnog mosta od vlakana nakon svetlosne polimerizacije

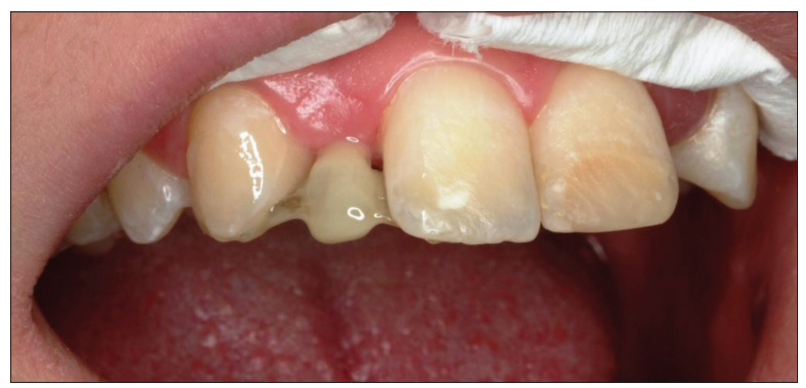

Figure 8. Modeling of the lateral incisor by composite layering technique

Slika 8. Modelovanje lateralnog sekutića tehnikom slojevitog nanošenja kompozita

were the length of interproximal space and a few mm longer on palatal surfaces of the abutment teeth. Enamel on palatal and proximal part of abutment teeth was etched with $37 \%$ phosphoric acid, rinsed with water, air dried and a thin layer of universal self etch adhesive G-aenial bond (GC, Europe) was applied (Figures 4,5). After curing a thin layer of flowable composite GC G-ænial Universal Flo (GC, Europe) was applied on prepared tooth surface. The fibers were placed using a special StickStepper instrument (GC, Europe) and then connector on one abutment tooth was light cured for 5-10 sec, while protecting with the instrument premature polimerization of the entire adapted fiber (Figures 6,7,8). Then after polymerization was carried out on the other connector. Gradual application and polymerization of the liquid composite layers formed the basis of the future adhesive bridge. The rest of the bridge was modeled using GC Gradia Direct composite (GC,Europe). The same procedure was repeated for the second adhesive bridge. The occlusion was checked and the restorations were polished (Figures 9, 10).

On the follow-up examination after two months, there was no observed damage of the bridges and a good oral hygiene was established. Patient was very pleased with the appearance and function of adhesive bridges.

\section{DISCUSSION}

Hypodontia of lateral incisors in young patients is difficult to treat and certainly conventional 3 unit bridges cannot be done [12]. On the other hand, even after the completion of development and growth bridges are inferior therapeu-

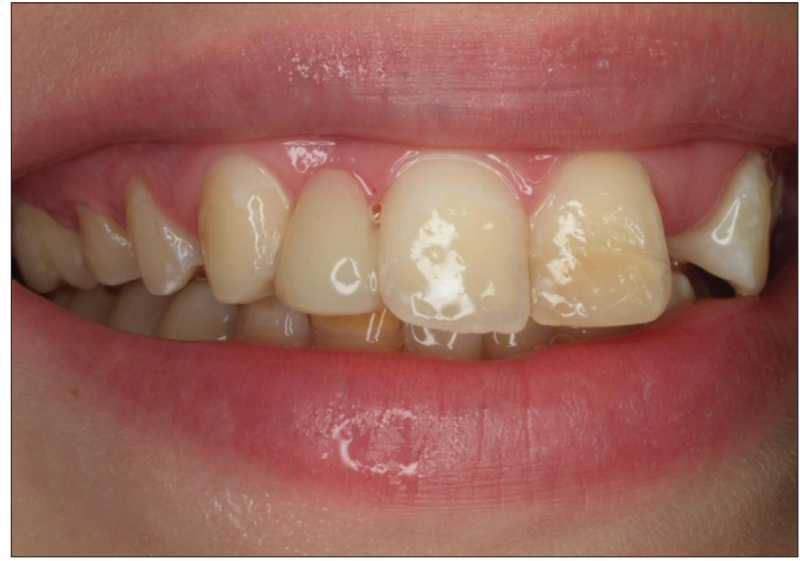

Figure 9. The appearance of the completed right adhesive bridge Slika 9. Izgled završenog desnog adhezivnog mosta

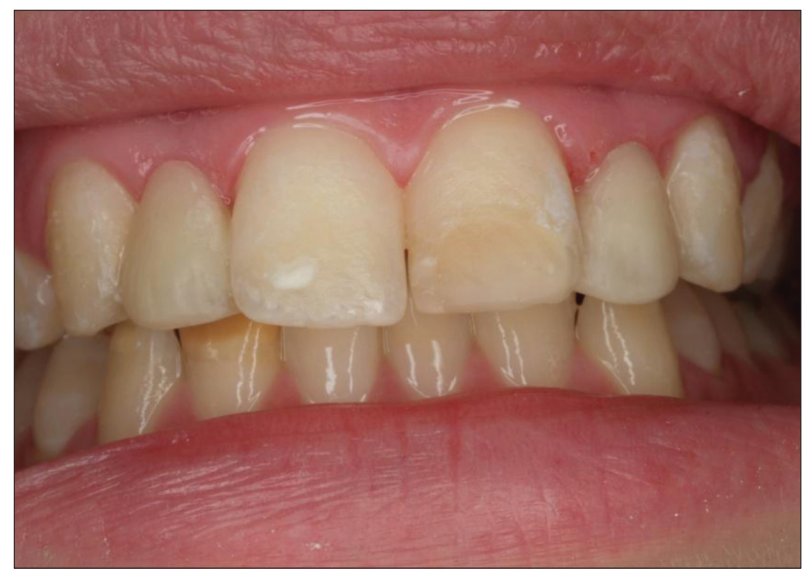

Figure 10. Final appearance of the patient after both adhesive bridges completion

Slika 10. Finalni izgled pacijenta po završetku oba adhezivna mosta

tic solution, because they reduce healthy tooth substance of the two supporting teeth and there is always danger of exposing the pulp during preparation $[13,7,14]$.

Another treatment option is Maryland Bridge with a preparation on the palatal surface of abutment teeth for rest placement. However, the biggest disadvantage of these bridges is the necessity for the preparation of healthy teeth and inadequate aesthetics of metal base [7]. With the advent of modern technology in dentistry, porcelain Maryland bridges are replacing metal base but they cost more. Partial denture is one treatment option but it often breaks and can cause irritation of palatal mucosa when used for a longer period of time [15]. Implants are an appropriate solution for the replacement of lateral incisors in the case of hypodontia, but patients consider it expensive and invasive treatment, and their fear and anxiety for surgical procedures must not be ignored $[7,13,15,16]$.

In the clinical case we presented, as well as in other similar studies, age of the patient was clear contraindication for implant placement [12]. For all these reasons it was decided to do minimally invasive, conservative solution, with the use of fiber reinforced composite resin until the definitive prosthetic-implant therapy.

In the previous years, the development of fiber-reinforced composites (FRC) provided an opportunity for dentists to produce adhesive, esthetic bridges even in 
one visit. FRC bridges are considered today an innovative solution and alternative to conventional fixed dental restorations and even implants in certain situations. In comparison with other prosthetic solutions, FRC bridges are quickly and easily made and they generally cost less [7]. Thin filaments incorporated into the base resin provide excellent resistance to fracture, fatigue, improved resistance to bending and tensile strength. The most common cause of failure is connector-cracking, delamination of the composite or fiber exposure [15].

Studies by other authors have shown the mean survival time of these bridges between 3-5 years, which makes them an appropriate transitional solution for the replacement of permanent anterior teeth in children. However, their disadvantages are reflected in the form of difficulty in maintaining oral hygiene as well as the inability to resist stronger occlusal forces $[17,18]$.

Within the limits of our study, we can say that adhesive bridges are quick, simple and clinically acceptable interim solution for the replacement of missing anterior teeth, but further clinical studies are required to verify their quality and efficiency.

\section{CONCLUSION}

The use of fiber-reinforced composites offers a unique and effective possibility for replacing missing teeth. This technology enables production of metal-free, cost-effective, minimally invasive restoration that preserves tooth structure. These bridges are considered temporary therapeutic solution before finalization of conventional fixed restorations or implant therapy.

\section{REFERENCES:}

1. Cunha RF, Delbem AC, Hirata E, Toyota E. Hypodontia in primary dentition: a case report. J Clin Pediatr Dent. 1999; 23(4):361-3. [PMID: 10551140]

2. Alves-Ferreira M, Pinho T, Sousa A, Sequeiros J, Lemos C, Alonso I. Identification of genetic risk factors for maxillary lateral incisor agenesis. J Dent Res. 2014; 93(5):452-8. [DOI: 10.1177/0022034514523986] [PMID: 24554542]
3. Finn SB. Clinical Pedodontics. 4th ed. Philadelphia: WB Saunders; 2004. pp. 224-270.

4. Pinkham JR. Pediatric dentistry: Infancy through adolescence. 4th ed. Missouri: Elsevier; 2005. pp. 341-374.

5. Olin PS, Hill EM, Donahue JL. Clinical evaluation of resin-bonded bridges: a retrospective study. Quintessence Int. 1999; 22(11):873-8. [PMID: 1812510]

6. Berekally TL, Smales RJ. A retrospective clinical evaluation of resinbonded bridges inserted at the Adelaide Dental Hospital. Aust Dent J. 1993; 38(2):85-96. [DOI: 10.1111/j.1834-7819.1993.tb05468.x] [PMID: 8494517]

7. Chafaie A, Portier R. Anterior fiber reinforced composite resin bridge: a case report. Pediatr Dent. 2004; 26(6):530-4. [PMID: 15646917]

8. Thilander B, Odman J, Lekholm U. Orthodontic aspects of the use of oral implants in adolescents: a 10-year follow-up study. Eur J Orthod. 2001; 23(6):715-31. [DOI: 10.1093/ejo/23.6.715] [PMID: 11890067]

9. Shah RA, Mitra DK, Rodrigues SV, Pathare PN, Podar RS, Vijayakar $\mathrm{HN}$. Implants in adolescents: a literature review and case reports. J Indian Soc Periodontol. 2013; 17(4):546-548. [DOl: 10.4103/0972-124X.118335]

10. Ganesh M, Tandon S. Versatility of ribbond in contemporary dental practice. Trends Biomater Artif Organs. 2006; 20(1):53-8.

11. Tuloglu N, Bayrak S, Tunc ES. Different clinical applications of bondable reinforcement ribbond in pediatric dentistry. Eur J Dent. 2009; 3(4):329-34. [PMID: 19826607]

12. Garoushi S, Lassila L, Vallittu PK. Resin-bonded Fiber-Reinforced Composite for direct replacement of missing anterior teeth: A Clinical Report. Int J Dent. 2011; 845420. [DOI: 10.1155/2011/845420]

13. Gerard J. Lemongello Jr. Fiber- reinforced bridge replacement for congenitally missing lateral incisors. Contemporary Esthetics And Restorative Practice, February 2001. http://www.aestheticadvantage. com/pdf/Lemongello-fiber-reinforced-bridge.pdf

14. Kermanshah H, Motevasselian F. Immediate tooth replacement using fiber-reinforced composite and natural tooth pontic. Operative Dentistry. 2010; 35(2):238-45. [DOI: 10.2341/09-136-S] [PMID: 20420068]

15. Bhargava S, Namdev R, Dutta S, Tiwari Rajkumar. Immediate fixed temporization with a natural tooth crown pontic following failure of replantation. Contemporary Clinical Dentistry. 2011; 2(3):226-9. [DOI: 10.4103/0976-237X.86468]

16. Kim H, Song MJ, Shin SJ, Lee Y, Park JW. Esthetic rehabilitation of single anterior edentulous space using fiber-reinforced composite. Restor Dent Endod; 2014; 39(3):220-5. [DOI: 10.5395/rde.2014.39.3.220]

17. Unlu N, Belli S. Three-year clinical evaluation of fiber-rein-forced composite fixed partial dentures using prefabricated pontics. J Adhes Dent. 2006; 8(8):183-8. [PMID: 16830665]

18. Freilich MA, Meiers JC, Duncan JP, Eckorte KA, Goldberg AJ. Clinical evaluation of fiber-reinforced fixed bridges. I Am Dent Assoc. 2002; 133(11):1524-34. [PMID: 12462697]

Received: 07.06.2016 • Accepted: 18.08.2016 


\title{
Vlaknima ojačan kompozitni most kao zamena za neiznikli gornji stalni lateralni sekutić - prikaz bolesnika
}

\author{
Ana Todorović, Danica Popović, Igor Đorđević, Vojkan Lazić \\ Univerzitet u Beogradu, Stomatološki fakultet, Klinika za stomatološku protetiku, Beograd, Srbija
}

\begin{abstract}
KRATAK SADRŽAJ
Hipodoncija gornjih lateralnih sekutića predstavlja značajan estetski problem mladih osoba. Idealno rešenje ovog problema bi predstavljala ugradnja implantata i izrada krunice, ali je prisutan problem nezavršenog rasta i razvoja. Zbog toga je neophodno izraditi privremeno rešenje, kako bi se normalno odvijale funkcije stomatognatnog sistema i rešili estetski problemi, sve do izrade trajne nadoknade.

Cilj ovog rada bio je da se prikaže mogućnost zbrinjavanja hipodoncije stalnih gornjih lateralnih sekutića izradom adhezivnog mosta u jednoj poseti.

Pacijentkinja starosti 15 godina javila se na Kliniku za stomatološku protetiku Stomatološkog fakulteta u Beogradu sa hipodoncijom stalnih gornjih lateralnih sekutića. $U$ anamnezi je navela da je nosila fiksni ortodontski aparat do svoje 14 . godine, a potom bila rehabilitovana parcijalnom pločastom protezom, kojom nije bila zadovoljna ni estetski ni funkcionalno, što je značajno uticalo na njenu emocionalnu nesigurnost. Izrađen je adhezivni most primenom GC kompozitnih vlakana i setom GC kompozitnih materijala sa ciljem privremene nadoknade neizniklih zuba.

Primenjenom terapijom je postignut zadovoljavajući funkcionalni i estetski rezultat do momenta realizacije trajnog protetskog rešenja. Sačuvan je prostor za ugradnju dva endosealna implantata, a period adaptacije je pozitvno uticao na socijalni razvoj osobe u osetljivom pubertetskom dobu.
\end{abstract}

Ključne reči: adhezivni mostovi; hipodoncija lateralnih sekutića; vlaknima ojačani kompoziti

\section{UVOD}

Hipodoncija ili nedostatak stalnih gornjih lateralnih sekutića uzrokovana je izostankom formiranja zubnih klica u vilici i javlja se u $20 \%$ populacije i to nešto češće u stalnoj nego u mlečnoj denticiji $[1,2]$. Pored funkcionalnog, hipodoncija predstavlja i značajan estetski problem mladim osobama u osetljivom periodu života. Rešavanje ovog problema nadoknadama visoke estetske vrednosti je uglavnom limitirano nezavršenim rastom i razvojem. Zamena prednjih zuba koji nedostaju, naročito kod dece, predstavlja veliki izazov za kliničare. Zato je multidisciplinaran pristup uz saradnju dečjeg stomatologa, ortodonta, protetičara i oralnog hirurga od izuzetnog značaja kako bi se očuvali prostor i noseća tkiva do definitivne terapije. Parcijalne proteze su često terapija izbora kod dece dok ne niknu stalni zubi (ne smanje se promene dimenzija alveolarne kosti i ne formiraju se komore pulpe) za kasniju izradu definitivne zubne nadoknade [3]. Ali, nedostatak brige o protezi od strane deteta i njeno habanje i akumulacija plaka predstavljaju najveća ograničenja ove terapije [4]. Metalokeramički mostovi se u ovim slučajevima isto odlažu do trenutka dok se ne uspostavi stabilnost marginalne gingive, a takođe kruta fiksacija između dva zuba dovela bi do ometanog rasta između njih. Maryland mostovi se takođe mogu koristiti kao zamena zuba koji nedostaju, ali im se zamera nedovoljna estetika usled prisustva metalne osnove i slabe veze između metalnih produžetaka i gleđi [5-7].

Dentalni implantati se, sa druge strane, ne preporučuju do završetka perioda rasta, zbog samog tipa veze implantata i kosti, jer za razliku od ankilotičnih zuba, oni ne prate rast kostiju lica i uvek je prisutna opasnost od njihove apikalne dislokacije $[8,9]$.

Minimalno invazivna terapija stvara mnogo veći izbor u daljem odabiru definitivne terapije. Metoda izbora je izrada adhezivnih mostova u cilju nadoknade neizniklih zuba i čini ekonomično i jednostavno rešenje koje daje dobre estetske rezultate u samo jednoj seansi.
Vlaknima ojačani kompoziti (FRC) materijali su na bazi smole koji sadrže vlakna koja poboljšavaju njihove fizičke karakteristike. Prvi put se u literaturi pominju 1960-ih, kada su staklena vlakna korišćena za ojačanje polimetil metakrilata [10].

Različite vrste vlakna, kao što su staklena, ugljenična, kevlar i polietilenska vlakna, dodavana su kompozitnim materijalima kako bi se unapredile njihove osobine [11].

U radu je opisana primena FRC tehnologije u izradi adhezivnih mostova kod hipodoncije stalnih gornjih lateralnih sekutića.

Cilj ovog rada bio je da se prikaže mogućnost zbrinjavanja hipodoncije stalnih gornjih lateralnih sekutića izradom adhezivnog mosta u jednoj poseti.

\section{PRIKAZ PACIJENTA}

Pacijentkinja starosti 15 godina se javila na Kliniku za stomatološku protetiku Stomatološkog fakulteta Univerziteta u Beogradu sa hipodoncijom stalnih gornjih lateralnih sekutića (Slika 1). Prethodne dve godine nosila je fiksni ortodontski aparat, a po završetku ortodontske terapije od svoje 14. godine bila je rehabilitovana parcijalnom pločastom protezom kao privremenim rešenjem. Parcijalna pločasta proteza nije joj više odgovarala u estetskom, a ni u funkcionalnom smislu, što je dovelo do njene emocionalne nesigurnosti (Slika 2). Nakon kliničkog pregleda i analize ortopantomografskog snimka uzeti su otisci za izradu modela za studije. Njihovom analizom u artikulatoru utvrđeno je da postoji dovoljno interokluzalnog prostora između gornjih i donjih prednjih zuba za izradu adhezivnog mosta retiniranog staklenim vlaknima bez potrebe za preparaciju ležišta. $\mathrm{Na}$ modelima za studije urađeno je i dijagnostičko modelovanje u vosku gornjih lateralnih sekutića, kako bi pacijentkinja imala uvid u izgled buduće nadoknade, i napravljen je silikonski ključ za oblikovanje sekutića koji su nedostajali na osnovu probnog 
modelovanja u vosku (Slika 3). Potom je, u jednoj poseti, direktnom metodom izrađen adhezivni most primenom GC Everstick C\&B fiber vlakana (GC, Europe) i setom GC Gradia kompozitnih materijala (GC, Europe) sa ciljem privremene nadoknade neizniklih zuba. Everstick C\&B vlakna napravljena su od preko 4000 E-staklastih silaniziranih vlakana okružena sa bis-GMA i polimetil metakrilatom (PMMA).

Potrebna dužina vlakana izmerena je na studijskom modelu. Vlakna su bila dužine interproksimalnog prostora sa prelaskom od nekoliko milimetara na palatinalne površine zuba nosača. Palatinalna i deo aproksimalne površine gleđi zuba nosača pripremljeni su rastvorom $37 \%$ ortofosforne kiseline, isprani vodom, posušeni vazduhom i nanet je jedan sloj univerzalnog samonagrizajućeg adheziva G-aenial bond (GC, Europe) (Slike 4 i 5). Nakon polimerizacije adheziva nanet je tanak sloj tečnog kompozita GC G-aenial Universal Flo (GC, Europe) na pripremljene površine zuba. Postavljeno je vlakno pomoću specijalnog Stick Stepper instrumenta (GC, Europe), a zatim izvršena svetlosna polimerizacija tokom 5-10 s spojnice na jednom zubu nosaću, istovremeno štiteći pomoću instrumenta da ne dođe do prerane polimerizacije celog adaptiranog vlakna (Slike 6,7 i 8). Zatim je izvršena polimerizacija druge spojnice. Postepenim nanošenjem i polimerizacijom slojeva tečnog kompozita formirana je osnova budućeg adhezivnog mosta. Ostatak mosta izmodelovan je korišćenjem GC Gradia direct kompozita (GC, Europe). Isti postupak je ponovljen i pri modelovanju drugog adhezivnog mosta. Izvršena je provera okluzije i nadoknade su ispolirane (Slike 9 i 10).

Na kontrolnom pregledu posle dva meseca nisu uočena bilo kakva oštećenja mostova i utvrđena je dobra oralna higijena. Pacijentkinja je bila veoma zadovoljna izgledom i funkcijom adhezivnih mostova.

\section{DISKUSIJA}

Hipodoncija lateralnih sekutića se kod mladih pacijenata ne može rešiti konvencionalnim mostovima od tri člana [12]. Sa druge strane, oni kao i definitivna nadoknada po završenom rastu i razvoju predstavljaju inferiorno terapijsko rešenje, jer se njima redukuje zdrava zubna supstanca dva noseća zuba i uvek postoji opasnost od eksponiranja pulpe prilikom brušenja $[13,7,14]$.

Druga terapijska mogućnost su Maryland mostovi sa preparacijom ležišta za naslone na palatinalnoj strani zuba nosača. Međutim, kao najveći nedostaci ističe se neophodnost za preparacije ležišta na zdravim zubima, kao i neadekvatna estetika metalne osnove [7]. Sa napretkom savremenih tehnologija u stomatologiji metalnu osnovu polako zamenjuju keramički Maryland mostovi, koji su znatno skuplji od konvencionalnih. Parcijalne pločaste proteze kao privremeno rešenje su sklone lomu i mogu dovesti do iritacije palatinalne sluzokože kada se koriste duži vremenski period [15]. Implantati predstavljaju odgovarajuće rešenje za zamenu lateralnih sekutića u slučaju hipodoncije, ali ih pacijenti smatraju skupim i invazivnim tretmanom, a ne sme se zanemariti ni strah i anksioznost pacijenata zbog hirurške procedure $[15,16,13,7]$. U kliničkom slučaju koji smo prezentovali, kao i u drugim sličnim studijama, godište pacijenta je bilo jasna kontraindikacija za njihovu ugradnju [12]. Zbog svega toga je odlučeno da se do definitivne protetsko-implantološke terapije primeni minimalno invazivno, konzervativno rešenje, uz upotrebu vlaknima ojačanih kompozitnih smola. Tokom prethodnih godina, razvoj vlaknima ojačanih kompozita (FRC) pružio je mogućnost stomatolozima da izrađuju adhezivne, estetske bezmetalne mostove čak u jednoj poseti. FRC mostovi smatraju se danas inovativnim rešenjem i alternativom konvencionalnim fiksnim zubnim nadoknadama, pa čak i implantatima u nekim situacijama. U poređenju sa drugim protetskim rešenjima, FRC mostovi se jednostavno i brzo izrađuju i generalno manje koštaju [7]. Tanki filamenti inkorporirani u osnovnu smolu omogućavaju odličnu otpornost na lom, zamor, poboljšanu otpornost na savijanje i zateznu čvrstoću. Najčešći uzrok neuspeha je pucanje spojnice, delaminacija kompozita ili eksponiranje vlakana [15].

Studije nekih autora su pokazale da je srednje vreme opstajanja ovih mostova od tri do pet godina, što ih čini odgovarajućim prelaznim rešenjem za zamenu stalnih prednjih zuba kod dece. Ipak, njihovi nedostaci se ogledaju u vidu teškoća u održavanju oralne higijene, kao i nemogućnosti da se odupru jačim zagrižajnim silama $[17,18]$.

U okviru ograničenja jednog prikaza slučaja iz prakse, može se reći da adhezivni mostovi predstavljaju brzo, jednostavno i klinički prihvatljivo, prelazno rešenje za zamenu prednjih stalnih zuba koji nedostaju, ali su potrebne dalje kliničke studije kako bi se potvrdio njihov kvalitet i efikasnost.

\section{ZAKLJUČAK}

Upotreba vlakanima ojačanih kompozita nudi jedinstvenu i efikasnu mogućnost zamene zuba koji nedostaju. Ova tehnologija omogućava izradu bezmetalne, ekonomične, minimalno invazivne nadoknade sa malim utroškom vremena i očuvanjem zubne supstance. Ovi mostovi se smatraju privremenim terapijskim rešenjem pre konačne izrade konvencionalnih fiksnih zubnih nadoknada ili implantološke terapije. 